Volume 3, Issue 1, February 2018, Pages: 252, DOI: http://dx.doi.org/10.19082/ah252

\title{
EVALUATION OF BIOMASS AND SUSCEPTIBILITY TO AMPHOTERICIN B IN BIOFILMS OF CANDIDA ALBICANS ISOLATED FROM CATHETERS AT THE UNIVERSITY HOSPITAL CENTER OF TLEMCEN (ALGERIA)
}

\author{
Zahia Boucherit-Otmani ${ }^{1}$, Kebir Boucherit ${ }^{2}$, Hidaya Fatima Zohra Touil ${ }^{1}$
}

1: Laboratoire Antibiotiques Antifongiques: Physico-chimie, Synthèse et Activité Biologique (LapSab). Université Abou bekr Belkaid Tlemcen

2: Centre universitaire d'Aïn Temouchent z_boucherit@yahoo.fr, boucheritkebir@yahoo.fr, hidayet_tlm@hotmail.fr

\section{TYPE OF ARTICLE: CONFERENCE ABSTRACT}

\begin{abstract}
Background: Systemic candidiasis is responsible for high morbidity and mortality and is mainly related to the use of modern and invasive techniques, particularly in immunocompromised patients. A significant proportion of these infections are associated with the formation of biofilms on various medical devices which are more resistant to environmental pressures and less accessible to antibiotics, which poses a clinical and economic problem for the management of invasive candidiasis in hospitals. Our work is in line with this objective and consists of evaluating the potential of Candida albicans isolated from medical devices of Tlemcen University Hospital (Algeria) which have formed biofilms, thus determining the sensitivity (SMIC) of Candida albicans strains against amphotericin B. XTT reduction assay was used to quantify the sessile growth.

Methods: Samples are collected aseptically and collected directly on sterile dry tubes from the intensive care units. The samples were incubated at $37^{\circ} \mathrm{C}$ for 24 to $48 / 72$ hours. Purified strains were identified by galleries Candida API ${ }^{\circledR}$ (Biomerieux).

The study of the susceptibility of Candida albicans to amphotericin B was determined using the microdilution method according to Pierce et al. 2008. XTT (2, 3-bis [2-methoxy-4-nitro-5-sulfophenyl]-2H-tetrazolium-5 carboxanilide) reduction assay was used to quantify the sessile growth by measuring the metabolic activity at 24 and $48 \mathrm{~h}$.

Results: All tested isolates produced biofilm on polystyrene, measured as XTT metabolic activity with variability in biofilm production. The biofilm metabolic activities (A $492 \mathrm{~nm}$ ) of C. albicans isolates at $48 \mathrm{~h}$ ranged between 0.51 and 1.26 . It was higher than at $48 \mathrm{~h}$.

The sessile cells of all isolated strains were much more resistant to AmB than planktonic cells, the SMIC of AmB ranged from 2 to $64 \mu \mathrm{g} / \mathrm{mL}$.

Conclusion: All the strains of C. albicans were able to form biofilms because the sessile minimum inhibitory concentrations (SMIC) are more above the minimum inhibitory concentrations (MIC).
\end{abstract}

KEYWORDS: Candida albicans, Amphotericin B, Biofilm, Biomass, XTT assay

\footnotetext{
Abstracts of Second International Conference on Health Sciences and Medical Technologies, 10-12 October 2017, Tlemcen, Algeria (ICHSMT-17)

(C) 2018 The Authors. This is an open access article under the terms of the Creative Commons Attribution-NonCommercialNoDerivs License, which permits use and distribution in any medium, provided the original work is properly cited, the use is non-commercial and no modifications or adaptations are made.
} 